\title{
Theorising attitude towards Islamic financing adoption in an integrative model of behavioural prediction: $A$ proposed conceptual framework
}

\author{
Purnomo M. Antara ${ }^{1,}{ }^{*}$, Rosidah Musa ${ }^{2}$, Faridah Hassan ${ }^{1}$ \\ ${ }^{1}$ Faculty of Business Management - Universiti Teknologi MARA, MALAYSIA \\ ${ }^{2}$ Institute of Business Excellence, Faculty of Business Management - Universiti Teknologi MARA, MALAYSIA
}

Keywords:

Attitude

Halalliteracy

Islamic finance

Islamic banking

Islamic financial literacy

Received: 29 May 2014

Accepted: 13 July 2015

Published: 15 October 2015

\begin{abstract}
Halal food and Islamic finance industry in Malaysia have been reported to be the two fastest growing Shari'a-compliant industries with an annual growth rate at 15\% to $20 \%$. Despite being the largest market in Islamic finance, there is a low penetration of Islamic financing among halal business operators in Malaysia. In fact, there is a limited empirical research on the linkage between halal food industry and Islamic finance industry. Thus, it is important to examine the connection between these industries. Besides, a study on the attitude of business operators towards Islamic financing is important to identify what factors may have influenced the attitude of halal business operators in choosing their financing method to either conventional or Islamic financing. This study aims at theorising attitude towards Islamic financing adoption using the Integrative Model of Behavioural Prediction (IMBP). An empirical study is conducted by reviewing literature and seven antecedents of attitude identified for the study. The proposed antecedents that influence attitude of food service business owners towards Islamic financing adoption include religion obligation, business support, cost benefits, reputation, customer service quality, Islamic financial literacy and Halal literacy. The research findings contribute towards new theoretical knowledge by discovering factors affecting the attitudes towards the adoption of Islamic financing in businesses using the IMBP theory. Besides, it may further help the government and policy makers in formulating strategies and policies related with the development of halal industry especially in integrating the halal production and Islamic financing.
\end{abstract}

(c) 2015 The Author(s). Publishred by TAF Publishing.

\section{INTRODUCTION}

The halal industry is becoming a new economic source and has begun to gain global attention not only from governments but also from business owners, bankers, academia and other institutions. Halal products and services are also gaining an increased acceptability not only from Moslems but also from others (Loo, 2010).

\footnotetext{
* Corresponding author: Purnomo M. Antara
}

E-mail address: purnomomantara@gmail.com
The development of halal industry is driven by several factors, including growths in the Moslem population and rising incomes among Moslem consumers that creates more demands for halal products and services.

In Malaysia, the country's Halal Master Plan has been approved by the Cabinet in May 2008. The Plan addresses several issues, e.g. certification, sectored development, implementation, responsibilities, Halal integrity and timeframes. Besides, the Plan envisions three phases of the roll-out during 2008-2020 (Figure 


\section{PHASE 1: 2008 - 2010}

Develop Malaysia as a global centre for Halal integrity and prepare the industry for growths

\section{PHASE 2: 2011 - 2015}

Establish Malaysia as one of the preferred locations for halal-related businesses
PHASE 3: 2016 - 2020

Broaden the geographical footprint of home-grown companies

FIGURE 1. Phases of Malaysia's Halal Master Plan (Bahli, 2011)

1). Malaysia is currently in the Phase 2 in which the government is trying to establish the country as a preferred location for halal-related businesses. The country has identified its focuses based on potential demands, opportunities and local capabilities to create economic impacts. Primary halal industries have been identified, including specially-processed foods, cosmetic \& personal care products, pharmaceutical, halal ingredients and livestock. Besides, enablers are identified, including legal, finance \& incentives, human capital, public sector delivery system, standards \& certification and infrastructure development to ensure the development of these focus areas.

In 2011, the Halal and Islamic finance industry have been reported by World Halal Forum to be the fastest growing Shari'a-compliant industries with an annual growth rate at $15 \%$ to $20 \%$. The integration of Halal and Islamic finance industries may have formed a strong economic platform that establishes a set of shared values and at the same time shapes the future global economy. As at April 2014, 2,353,108 applications for Malaysia's Halal Certification are taken by a total of 4,081 companies (HDC, 2014). Malaysia has a thriving halal food-processing industry, and the government has stated its intention of turning the country into a global hub for halal produces. In fact, Malaysia's Halal certification has been recognised worldwide, while the halal certification fulfills ISO compliant standards (MS1500: 2004). It is developed by the Department of Standard Malaysia, which includes Standards for the Production, Handling and Storage of Halal food. The standards also comply with international standards such as the Good Manufacturing Practice (GMP) and the Good Hygiene Practice (GHP).

Sayyiduna Abu Hurayrah (radhiallahu anhu) has reported that the Prophet (salallahu alaihi wasallam) has sought: "A time will come upon the people wherein a man will not bother what he intakes; whether from a halal source or haram" (The Hadith, n.d.). The concept of Halal refers to the way of producing goods and services in a manner approved by Islamic law and Shari'a, while it may include not only food products and preparation but also financial practices. Jaffar \& Musa (2013) have stated that a company should focus on adopting halal financing rather than only focusing on halal production in order to being a correct Halal business operator. In fact, Malaysia have provided end-to-end Halal services: from traceable halal product to Islamic finance service. The country has shown a significant growth in Islamic financing with an average annual growth rate of $16.07 \%$ during 2002-2011. Noticeably, the financing has been penetrating the Western world as well (Laldin \& Furqani, 2013). However, there have been few studies on the integration of halal-food producers and halal-financing adoption. World Halal Conference 2015 has discussed the opportunities in Halal industry and reported that there is a low integration between the Halal industry and the entire value-chain system, including Islamic financing. In particular, Jaffar \& Musa (2013) have noted that the issue occurs in Malaysia, which is witnessed by the low penetration of Islamic finance among players within the Halalindustry.

Furthermore, Jaffar \& Musa (2013) have conducted a study on attitude towards halal business owners to understand any factors that may affect the attitude of business owners towards their intention to use Islamic financing. Previous studies have identified factors that affect the formation of attitude among business owners towards intention to adopt Islamic financing from the perspectives of individual customers and commercial firms. However, none of the studies have adopted the Integrative Model of Behavioural Prediction (IMBP) as the basis of investigation. Besides, there is a lack of literature that have theorised the Halal literacy and Islamic financing literacy on the attitude towards an intention to use Islamic financing.

\section{LITERATURE REVIEW}

\section{Islamic Financing Concept}

Islamic financing in business includes equity, debt and derivatives with four main components, i.e. Islamic banking, Islamic capital market, takaful \& re-takaful and Islamic interbank money market (HDC, 2014). In general, Islamic financing activities are managed by Islamic banking. Islamic banking is a branch of Islamic finance that is based on a Shari'a (Islamic law) called fiqh muamalat (Islamic rules on transactions). The 
rules come from the Qur'an, the Sunnah and other secondary sources of Islamic law, e.g. collective opinions by Shari'a scholars (ijma), analogy (qiyas) and personal reasoning (ijtihad). The most popular financing concepts are Bai Bithaman-Ajil, Ijarah Thumma Al-Bai and Murabahah (PwC, 2008).

\section{Malaysia as an International Islamic Finance Hub}

The first Islamic bank in Malaysia was established in 1983. A decade later, commercial and merchant banks alongside finance companies began to offer Islamic banking products and services under Islamic Banking Scheme (IBS Banks). The scheme requires banks to separate their funds and activities of Islamic banking transaction from non-Islamic banking. Islamic finance market development in Malaysia is regulatory guided by two Shari'a Advisory Councils (SACs) under the Securities Commission Malaysia and Bank Negara Malaysia. In 2000, these advisory councils have outlined the strategic directions for the country's Islamic financial sector through the Master Plan of Malaysia's financial sector and capital market. In 2006, the Malaysia International Islamic Financial Centre (MITC) was set up to strengthen the country's role as an intellectual epicentre for Islamic finance. In fact, the country's Islamic financing industry has achieved a significant growth with an average annual growth rate of $16.07 \%$ during 2002-2011 (HDC, 2014). The efforts and policies implemented have resulted Malaysia as a forefront of Islamic finance and also one of the largest Islamic finance markets in the world. PwC (2008) has reported that Malaysia is the world's largest issuer of Sukuk and unit trust industries.

\section{Past Studies on Attitude towards Islamic Financing} Jaffar \& Musa (2013) have proposed five antecedents of attitude towards intention to use Islamic financing. In this study, all those variables are adopted and extended using the IMBP. Despite the existence of empirical works conducted to examine the attitude towards Islamic financing from the perspective of business firm (Gait \& Worthington, 2009; Osman \& Ali, 2008; Ahmad \& Haron, 2002; Jalaluddin, 1999; Edris, 1997) and consumers (Loo, 2010; Hudayati \& Auzair, 2009; Ramdhony, 2013), this study adds three additional antecedents, i.e. customer service quality, Halal literacy and Islamic financial literacy into the framework. Besides, no existing study has attempted to theorise the attitude towards Islamic financing using the IMBP theory.

\section{CONCEPTUAL FRAMEWORK}

The Integrative Model of Behavioural Prediction

Ajzen \& Fishbein formulated the Theory of Reasoned Action (TRA) in 1980, resulting from a research over attitude based on the Expectancy Value Models (EVM) after attempted to estimate the discrepancy between attitude and behaviour. While TRA is stated as related to voluntary behavior, Ajzen (1985) later discovered that behaviour is not $100 \%$ voluntary, and it is in fact under control. It results in additional factors that lead to intention, i.e. perceived behavioural control and the Theory of Planned Behaviour (TPB). The TPB was first developed in 1988, and it is a theory that predicts deliberate behaviour because behaviour may be either deliberate or planned. The theory proposes a model that may measure how human actions are guided, and it predicts the occurrence of a particular behaviour, provided that the behaviour is intentional.

The TPB was then modified by Fishbein (2000) through the IMBP theory. It was further expanded by Fishbein \& Yzer (2003), in which they used the IMBP as a tool for designing and evaluating health behaviour change interventions. The theory represents the latest formulation of the reasoned action approach, which includes the TRA (Ajzen \& Fishbein, 1980; Fishbein \& Ajzen, 1975) and the TPB (Ajzen, 1985). In parallel, Fishbein has also stated that the IMBP may also be taken not only for predicting health behaviour but also for any behaviour (Fishbein, 2008). In this study, the IMBP is taken to theorising attitude towards intention to adopt Islamic financing instruments. Antecedents of the attitude of business firms toward Islamic financing are identified and suggested as a framework.

\section{The Food Service Industry in Malaysia}

The food service industry is a fast-growing sector in Malaysia. An increased income within Moslem society has led to an increase in demand on food services. Thus, food service organisations in Malaysia require a halal license from JAKIM to cater the demand from Moslem people. MSIC (2008) has defined food service as a group including the provision of food services to customers. It is possibly served while seated or selfservice from a display of items, and whether they eat prepared meals on the premises, take them out or have them delivered. Food service companies include restaurants and restaurant cum nightclubs, cafeterias or canteens, fast-food restaurants and food stalls. In this study, the population includes organisations (companies or business) registered at Suruhanjaya Syarikat Malaysia (SSM), which is engaged in the Halal 
food and beverage services in Malaysia, including food provision services, event catering and other activities.

Furthermore, the seven antecedents of attitude are integrated into the IMBP as a new approach in determining consumers' attitude towards Islamic financing. The antecedents taken in this study include religion obligation, business support, cost benefits, reputation, customer service quality, Halal literacy and Islamic financial literacy. The research model is tested and validated in a research setting over Halal food service industry. Then, research findings are expected to generalise the antecedents of attitude among the owners of food service businesses towards adoption of Islamic financing for their business.

\section{The Conceptual Framework}

Although a lot of variables may influence a behaviour, predicting behaviour in a dedicated population may need to consider only a certain number of variables (Figure 2) (Fishbein \& Ajzen, 1975, 2010). Next, three determinants of intention include Attitude, Subjective Norm (Ajzen \& Fishbein, 1980) and Perceived Behavioural (Ajzen, 1985). Jaffar \& Musa (2013) have identified the antecedents of attitude, i.e. Religion Obligation (Thambiah, Eze, Tan, Nathan, \& Lai 2010), Cost Benefits (Thambiah et al., 2010), Business Support (Durkin, McGowan, \& Babb, 2013) and Reputation (Jun \& Jaafar, 2011), as the determinants of attitudes towards intention to use Islamic financing. Besides, three additional antecedents include Customer Service Quality (Othman \& Owen, 2001), Halal Literacy (Salehudin, 2010) and Islamic Financial Literacy.

Intention towards behaviour. According to Fishbein (2008), intention is probably the best single predictor that leads to perform or not to perform a behaviour. However, intention does not always predict a said behavior, although an individual may have a positive intention; the person may be unable to perform the behaviour. Even though most studies have found that people may not perform a correct behaviour because they do not have all the relevant information, which means they have a wrong attitude, Fishbein (2008) has stated that the problem occurs because people cannot act on their intention to perform the behaviour. In fact, Fishbein (2000) has identified two interventions: Skills and Environmental Factors. Despite having a correct attitude, a person who does not perform a behaviour may be affected by internal and external barriers preventing one from acting on one's intention.

Determinants of intention. Three determinants of intention include Attitude, Subjective Norm (Ajzen \& Fishbein, 1980) and Perceived Behavioural (Ajzen, 1985). Attitude towards a behaviour can be defined as individual's favourable or unfavourable views on a behaviour. On the other hand, subjective norms are a set of beliefs over what other people think a person may need to do. Besides, it also determines the degree on how a person is motivated by what others think. Then, perceived behavioural control means believing that behaviour is within one's control, noting that the perception of a behaviour performance, either hard or simple, may affect intention (Ajzen, 1985).

Antecedents of attitude. In order to understand the behaviour of adopting Islamic financing from the perspective of population, a set of salient beliefs needs to be determined (Fishbein, 2008). In this study, seven salient beliefs, as a set of the antecedents of attitudes,

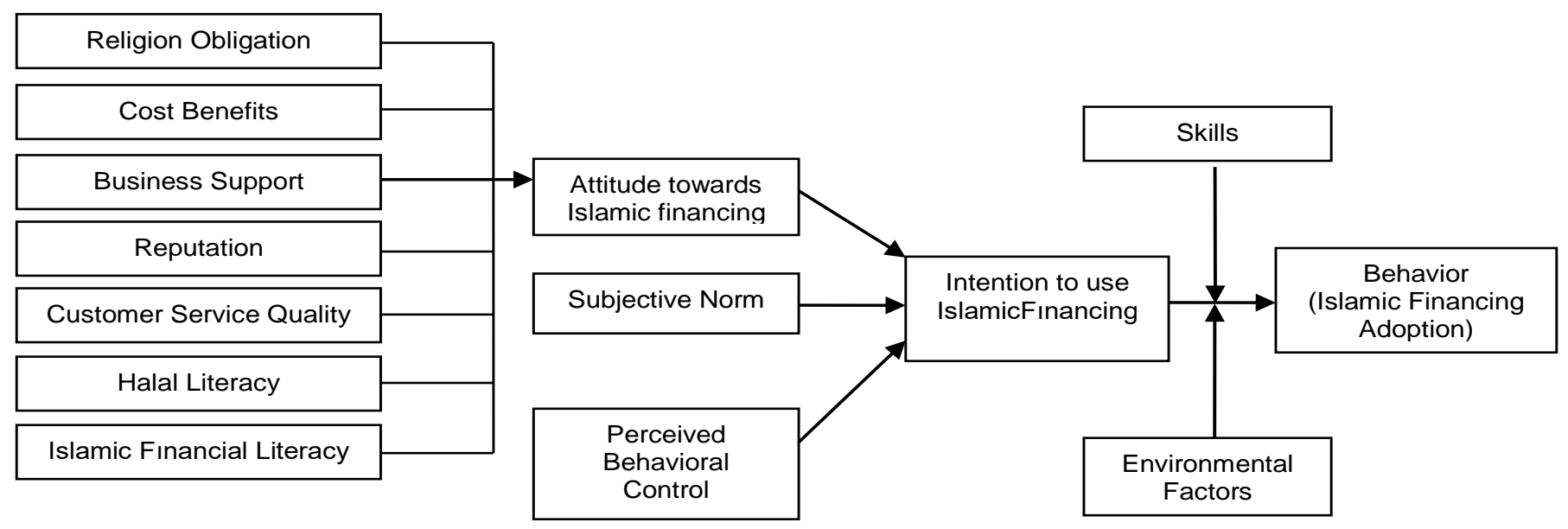

FIGURE 2. The proposed conceptual framework 
are identified, including reputation, business support, customer service quality, cost benefits, Halal literacy, religion obligation and Islamic financial literacy that influence attitude towards Islamic financing adoption.

Religious obligation. Amin, Abdul Rahman, \& Sondoh (2011) have defined religion obligation as the role of religion in affecting an individual's choice or activities. Religiosity is critically important due to its capability of influencing individual cognitively and behaviourally (Alam, Jano, Wel, Aniza, \& Ahsan, 2012), while each person has different value and the level of religiosity. Besides, Jaffar \& Musa (2013) have also suggested that a greater adherence to Islamic principle may form the most favourable attitude.

Cost benefits. The relative advantage or cost benefit is identified as a factor influencing the attitude towards intention in adopting a product or service. In general, every potential adopter has a basic desire to know the level or degree to which a new product is better than existing ones (Thambiah et al., 2010).

Business support. Current banking system has begun to shift from a transaction-oriented business model to a relationship-oriented one (Webster, 1992; Dibb \& Meadows, 2001). Business support from financial institutions is identified as important thing because small organisations may also contribute to bank profits, while the owners of small firms may also be interested in improving their relationship with banks if they get proper financial support and advice (Durkin et al., 2013). Yusoff \& Yaacob (2010) have suggested two types of business support, i.e. financial supports (property loan, working capital and grant) and nonfinancial ones (management, distribution, research \& development, courses and advisory). Jaffar \& Musa (2013) have suggested that the business supports of financial institutions and agencies providing Islamic method of finance may influence the attitude of those firms towards intention to adopt Islamic financing.

Reputation. Jun \& Jaafar (2011) have identified that reputation may have been influencing the attitude of consumers to adopt a product or service. Reputation refers to the social responsibility and social objectives of a Halal financial institution (Jaffar \& Musa, 2013). Reputation is based on perceptions of the reliability, credibility, social responsibility and trustworthiness of an organisation (Fombrun, 1996).
Customer service quality. Lin \& Bennett (2014) have found that customers experience may have been influencing their satisfaction and loyalty. Customers who are satisfied with previous products or services provided by an organisation tend to adopt the product or service again (Grace \& O'Cass, 2004). Othman \& Owen (2001) have found that customer service quality is important to ensure customer satisfaction in Islamic finance industry. In this study, customer service quality is expected to influence attitude towards the adoption of Islamic financing.

Halal literacy. It refers to the ability to differentiate permissible (halal) and forbidden (haram) products or services, which comes from a proper understanding of Islamic law (Salehudin, 2010). According to Rogers (2003), consumers may go through the process of knowledge, persuasion, decision and confirmation before they are ready to adopt a product or service. Besides, consumer awareness is one of key variables that influence the intention of using a product or service (Thambiah et al., 2010), while the degree of the awareness and knowledge on Islamic financing may influence attitude towards Islamic financing (Jaffar \& Musa, 2013). Thus, a higher literacy on halal-related issues is expected to influence a positive attitude towards Islamic financing adoption. Then, Salehudin (2010) has identified two approaches in measuring the literacy, i.e. using a test-based true-false questions and using a 5-point Likert-based scale to measure the SelfEvaluated Halal literacy of a customer.

Islamic financial literacy. The concept of financial literacy has been studied by many researchers (Cho \& $\mathrm{Hu}, 2009$; Glaser \& Weber, 2007), who have found that financial literacy may have been influencing a person in performing a behaviour. Besides, each person has a different level of financial literacy, and the difference may then influence the behaviour. However, there is no study on financial literacy that focuses on Islamic finance concept. In this study, Islamic financial literacy is examined to discover if it has affected the attitude of business owners in adopting Islamic financing.

\section{CONCLUSION AND IMPLICATIONS}

The proposed conceptual framework of IMBP in Islamic financing adoption may help the identification of beliefs that have influenced a behaviour. Religion obligation, cost benefits, business support, reputation, customer service quality, halal literacy and Islamic financial literacy are identified as determining factors 
of attitude towards Islamic financing adoption. This study attempts to link the Halal industry and Islamic financing Industry. Research findings are expected to be a platform to understand factors affecting attitude towards Islamic financing adoption. Thus, the findings may help the government and policy makers in formulating strategies and policies related to the Halal industry, particularly in integrating halal production and Islamic financing. It may then help to strengthen the Islamic financial abilities and capabilities of many stakeholders; hence more Islamic financing will be adopted by halal food producers. The research findings are also expected to strengthen halal infrastructure in Malaysia as one of Halal-hubs in the world.
Furthermore, the current study is limited on food service industry, meaning that the results may differ in other industrial sectors. Thus, a future research is suggested to observe the attitude of business owners towards Islamic financing in different halal industries.

\section{ACKNOWLEDGEMENT}

The authors would like to thank The Ministry of Education (MOE), for providing the Fundamental Research Grant Scheme (FRGS), and Universiti Teknologi MARA (UiTM), for providing assistance and helps in facilitating this research.

\section{REFERENCES}

Ahmad, N., \& Haron, S. 2002. Perceptions of Malaysian corporate customers towards Islamic banking products and services. International Journal of Islamic Financial Services, 3(4): 13-29.

Ajzen, I. 1985. From intentions to actions: A theory of planned behavior. In J. Kuhl \& J. Beckmann (Eds.), Action-control: From cognition to behavior, 11-39. Heidelberg, DE: Springer-Verlag.

Ajzen, I. \& Fishbein, M. 1980. Understanding attitude and predicting social behavior. New Jersey, US: Prentice-Hall.

Alam, S.S., Jano, Z., Wel, C., Aniza, C., \& Ahsan, N. 2012. Is religiosity an important factor in influencing the intention to undertake Islamic home financing in the Klang Valley?. World Applied Sciences Journal, 19(7): 1030-1041. DOI: 10.5829/idosi.wasj.2012.19.07.392

Amin, H., Abdul Rahman, A.R., Sondoh, S.L., \& Chooi-Hwa, A.M. 2011. Determinants of customers' intention to use Islamic personal financing: The case of Malaysian Islamic banks. Journal of Islamic Accounting and Business Research, 2(1): 22-42. DOI: 10.1108/17590811111129490

Bahli, S.. 2011. Awareness of the Halal industry. International Halal Conference Pakistan 2011, Karachi, PK, 22-23 March.

Cho, J.E., \& Hu, H. 2009. The effect of service quality on trust and commitment varying across generations. International Journal of Consumer Studies, 33(4), 468-476. DOI: 10.1111/j.1470-6431.2009.00777.x

Dibb, S., \& Meadows, M. 2001. The application of a relationship marketing perspective in retail banking. Service Industries Journal, 21(1): 169-194. DOI: 10.1080/714005011

Durkin, M., McGowan, P., \& Babb, C. 2013. Banking support for entrepreneurial new venturers: Toward greater mutual understanding. Journal of Small Business and Enterprise Development, 20(2): 420-433. DOI: $10.1108 / 14626001311326806$

Edris, T. A. 1997. Services considered important to business customers and determinants of bank selection in Kuwait: a segmentation analysis. International Journal of Bank Marketing, 15(4): 126-133. DOI: 10.1108/02652329710189393

Fishbein, M. 2000. The role of theory in HIV prevention. AIDS care, 12(3): 273-278. DOI: 10.1080/09540120050042918

Fishbein, M. 2008. A reasoned action approach to health promotion. Medical Decision Making, 28(6): 834-844. DOI: 10.1177/0272989X08326092

Fishbein, M. \& Ajzen, I. 1975. Belief, attitude, intention and behavior: An introduction to theory and research. Ontario, CA: Addison-Wesley Pub. Co.

Fishbein, M., \& Ajzen, I. 2010. Predicting and changing behavior: The reasoned action approach. New York, US: Psychology Press.

Fishbein, M., \& Yzer, M.C. 2003. Using theory to design effective health behavior interventions. Communication Theory, 13(2): 164-183. DOI: $10.1111 / j .1468-2885.2003 . t b 00287 . x$

Fombrun, C.J. 1996. Reputation: Realizing value from the corporate image. Boston, US: Harvard Business School Press.

Gait, A. \& Worthington, A. 2009. Libyan business firm attitude towards Islamic methods of finance. Social Science Research Network. DOI: 10.2139/ssrn.1370752

Glaser, M., \& Weber, M. 2007. Why inexperienced investors do not learn: they do not know their past portfolio performance. Finance Research Letters, 4(4): 203-216. DoI: 10.1016/j.frl.2007.10.001 
Grace, D., \& O'Cass, A. 2004. Examining service experiences and post-consumption evaluations. Journal of Services Marketing, 18(6): 450-461. DOI: 10.1108/08876040410557230

HDC. 2014. Halal Certified Statistic. HDC. URL: www.hdcglobal.com/publisher/gwm_industry_statistics

Hudayati, A., \& Auzair, S. M. 2009. Performance measurement system, attitude toward risk and the performance of profit sharing financing in Indonesian Islamic bank. Jurnal Pengurusan, 29: 75-94.

Jaffar, M.A., \& Musa, R. 2013. Determinants of attitude towards Islamic financing among Halal-certified micro and SMEs: A proposed conceptual framework. International Journal of Education and Research, 1(8): 1-10.

Jalaluddin, A. 1999. Attitudes of Australian financial institutions towards lending on the profit/loss sharing method of finance. PhD Dissertation, University of Wollongong, New South Wales, AU.

Jun, G., \& Jaafar, N.I. 2011. A study on consumers' attitude towards online shopping in China. International Journal of Business and Social Science, 2(22): 122-132.

Laldin, M.A., \& Furqani, H. 2013. Developing Islamic finance in the framework of maqasid al-Shari'ah: Understanding the ends (maqasid) and the means (Wasa'i). International Journal of Islamic and Middle Eastern Finance and Management, 6(4): 278-289. DOI: 10.1108/IMEFM-05-2013-0057

Lin, Z., \& Bennett, D. 2014. Examining retail customer experience and the moderation effect of loyalty programmes. International Journal of Retail \& Distribution Management, 42(10): 929-947. DOI: 10.1108/IJRDM-11-2013-0208

Loo, M. 2010. Attitudes and perceptions towards Islamic banking among Moslems and non-Moslems in Malaysia: implications for marketing to baby boomers and x-generation. International Journal of Arts and Sciences, 3(13): 453-485.

Othman, A., \& Owen, L. 2001. Adopting and measuring customer service quality (SQ) in Islamic banks: A case study in Kuwait finance house. International Journal of Islamic Financial Services, 3(1): 1-26.

Osman, M.R. \& Ali, H. 2008. Exploring Moslem entrepreneurs' knowledge and usage of Islamic financing. Seminar Keusahawanan Islam II Peringkat Kebangsaaan, Kuala Lumpur, MY, 15 October.

PwC. 2008. Malaysia, Asia's Islamic finance hub. PricewaterhouseCoopers. URL: goo.gl/9WQ1Xj

Ramdhony, D. 2013. Islamic banking awareness attitudes and bank selection criteria. International Journal of Humanities and Applied Sciences, 2(2): 29-35.

Rogers, E.M. 2003. Diffusion of innovations (5th ed.). New York, US: Free Press.

Salehudin, I. 2010. Halal literacy: A concept exploration and measurement validation. ASEAN Marketing Journal, 2(1): 112. DOI: $10.2139 / \operatorname{ssrn} .2004762$

Thambiah, S., Eze, U.C., Tan, K.S., Nathan, R.J., \& Lai, K.P. 2010. Conceptual framework for the adoption of Islamic retail banking services in Malaysia. Journal of Electronic Banking Systems, \#750059.

The Hadith, (pp. Sahih Bukhari, Book 34, Hadith Number 13)

Webster, F.E. 1992. The changing role of marketing in the corporation. Journal of Marketing, 56(4): 1-17. DOI: $10.2307 / 1251983$

Yusoff, M.N.H.B., \& Yaacob, M.R.B. 2010. The government business support services in Malaysia: the evolution and challenges in the new economic model. International Journal of Business and Management, 5(9): 60-71. DOI: 10.5539/ijbm.v5n9p60

- This article does not have any appendix. - 